\title{
ENERGISING ELECTRONICS ENGINEERING: IMPROVING LEARNING BY FLIPPING THE CLASSROOM AND GOING ONLINE
}

\author{
Mikkel Godsk, Hans Jørgen Hansen, Mikael Bergholz Knudsen, Mette Ramsing \\ Lindhardtsen, Per Lysgaard, Henning Slavensky
}

Aarhus University (DENMARK)

\begin{abstract}
In 2014, the Electronics Engineering study programme at Aarhus University School of Engineering in Herning was threatened with closure due to a continuous decline in student intake. Consequently, the programme management decided in 2014 to completely rethink the programme. This paper presents how this closure-threatened study programme at Aarhus University (AU) was 'energised' by flipping the teaching practice to an online format in 2015, improving the learning for face-to-face students and increasing intake. The background, development process, learning design and impact are presented as well as the lessons learnt. The paper concludes that it is indeed possible to 'energise' the programme and at the same time improve learning for face-to-face students.
\end{abstract}

Keywords: STEM education, flipped classroom, blended learning, online learning, learning design, engineering.

\section{BACKGROUND}

Herning is a mid-sized city with a population of 48,000 inhabitants located 87 kilometres from Aarhus, the second largest city in Denmark. Herning has an engineering campus organised under AU to support the local wind turbine industry. There is a general trend in Denmark that young people prefer to study in the big cities. This indeed had a significant impact on the student intake in Herning. In 2014 the student intake was at an all-time low and the education was no longer sustainable in its then form (Table 1). To recruit more students, it was necessary to differentiate the study programme from the major engineering colleges in the big cities. However, a change of curriculum was not on the agenda, due to the local industry lacking engineers with the qualifications provided. Consequently, it was decided to differentiate the education by changing the teaching method and include an online option to recruit new groups of students from all over Denmark. The vision of the new study programme was: 'More and better engineers in Herning' and the mission was to 'create a study programme which included both face-to-face and online students', 'have a good study environment for both face-to-face and online students', 'include unique teaching methods', 'stand out positively from existing engineering programmes' and 'give the students the opportunity to follow the teaching independently of time and place' [1]. The target group is engineering students who want to join an educational network consisting of students on campus, from home, from a workspace, or from abroad.

The goal was a minimum intake of 35 students and the method was to energise and redefine the teaching concept supplemented with an extensive marketing-effort. In order to energise the programme and aiming at both face-to-face and online students, it was necessary to rethink all parts of the education, including the teaching methods, study environment, international opportunities, innovation and entrepreneurship, laboratories and business cooperation. 


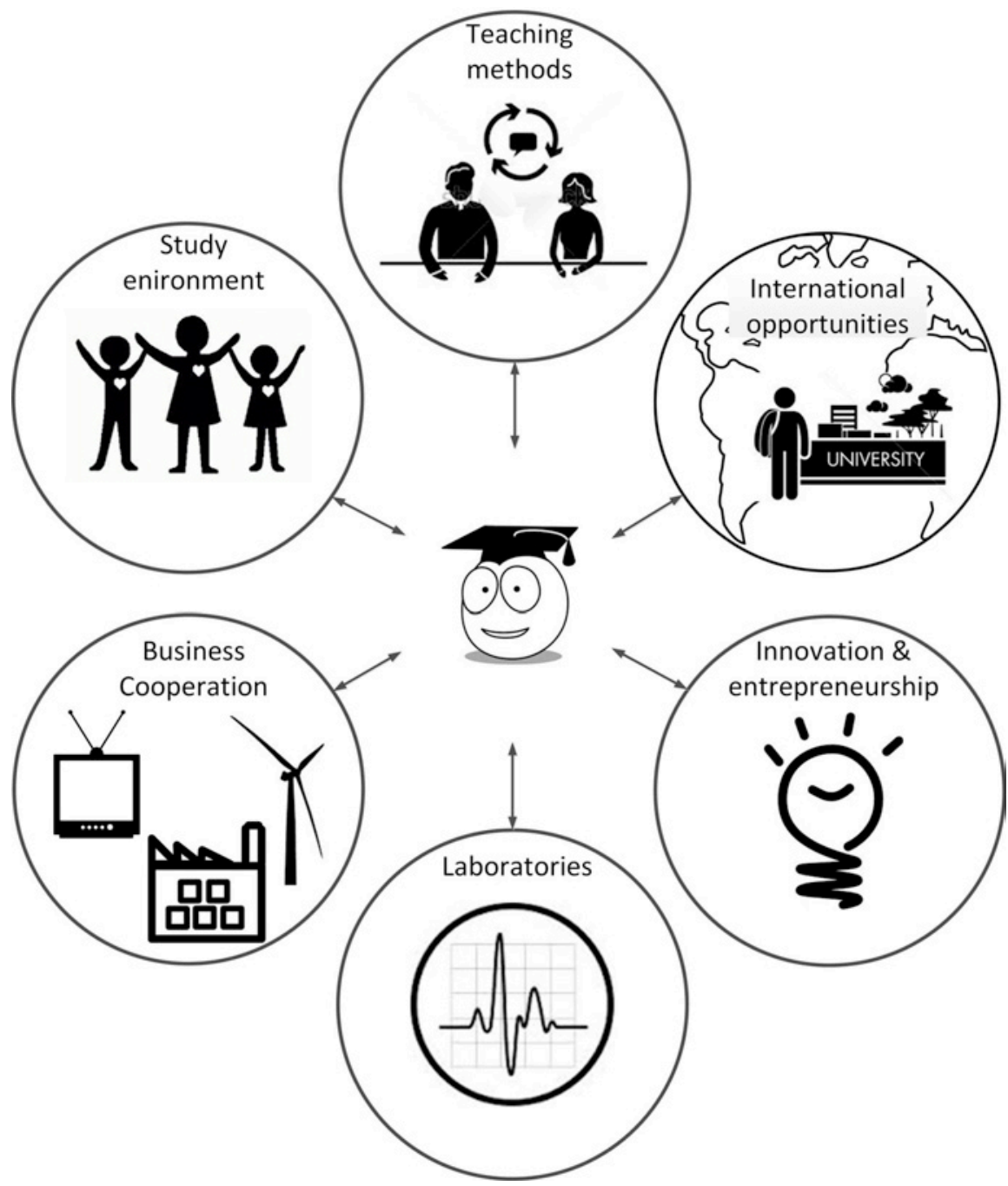

Figure 1: The programme focuses on new teaching methods, creating a good study environment, international opportunities, innovation and entrepreneurship, laboratories and business cooperation.

\section{THE DEVELOPMENT PROCESS}

To run the innovation process, the entire teaching staff met, and a design thinking methodology was adopted of five phases: discovery, interpretation, ideation, experimentation and evolution [2]. It provided a common ground for developing the new concept within the group, and the outcome was the detailed concept that has been implemented today. The design thinking method nourished the creative process, ensuring that all team members were on the same page, and knew the expected outcome of each phase. The concept was ready by the end of 2014 and implemented within the first six months of 2015 using a traditional stage-gate project management approach [3]. A full-time professional project manager was appointed from 2015 with a detailed organisational knowledge of $\mathrm{AU}$ and its IT systems. The combination of dedicated project management, a design thinking methodology to develop the new concept and a stage-gate approach for an efficient implementation worked well and resulted in a fast launch of the new programme. The result was a new pedagogical approach rather than a change of curriculum. By introducing the principles of 'flipped classroom' [4], 'Just-in-Time Teaching' [5] and 'the STREAM learning design' [6] (Figure 2) concurrently with providing an online parallel version, where students could follow all teaching activities without having to go to campus, the study programme now appealed to a whole new segment of students. Through an intensive course and a number of seminars, the teaching staff was introduced to the flipped classroom concept and STREAM learning design as well as online teaching and learning facilitated by a technical set-up based on video conferencing and the mobile kit 'Lab-in-a-box' (Figure $3+4$ ). 


\section{LEARNING DESIGN}

The study programme is divided into seven semesters, each covering a number of courses and projects (a total of 30 ECTS credits per semester). The courses are typically between 5-10 ECTS; however, with a majority of 5 ECTS. The courses that have been flipped must be updated and refined continuously based on experience and classroom reception, but in essence, the courses can be and are reused.

The flipped courses (equivalent to 120 ECTS credits in total) take place in the first four semesters, where the students learn basic project skills and a fixed core curriculum. Currently, there are no further plans to flip more courses. From the fifth semester and onwards, the students engage in four individually chosen electives (20 ECTS credits in total) as well as a company placement. The electives that are offered reflect current trends in the field of electronics engineering, and are to some extent based on the students' wishes. Furthermore, the students can also choose from a select few courses which take place at $A U$ in Aarhus. As such, there is no clear case for flipping these courses. The students, however, are offered continuous and systematic feedback from the educators.

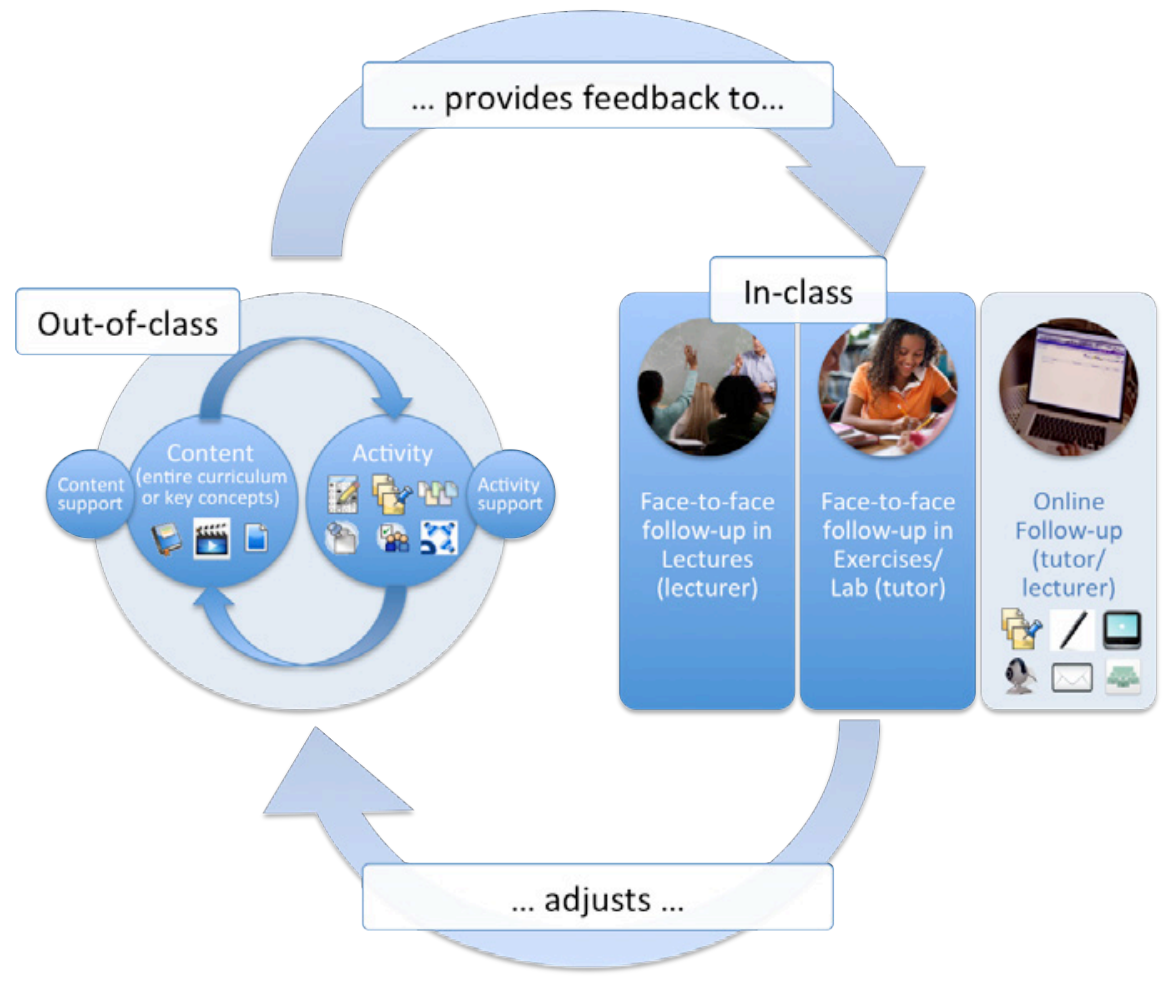

Figure 2: The STREAM learning design model.

The structure of a flipped course roughly follows the STREAM learning design model (Figure 2): The educator publishes videos, texts and exercises in Blackboard learning management system at least one week in advance on any given lecture/lesson so that the students can access it out-of-class. For each class, the students must take a test in-class or out-of-class. Based on the results of the test, the educator adjusts his presentation and exercises to covering areas that seem particularly difficult for the majority of the students. Subsequently, the students - face-to-face and online - engage in exercises in-class or online on the basis of the teaching material. The educator helps where needed while, at the same time, taking into account the actual skill level of the student. Since all presentations are streamed and recorded, asynchronous online students can watch the material until the exercise part at home, since the exercise part is rarely recorded due to their individual nature. Instead, these students have regular online meetings with the educators when it best suits them. 


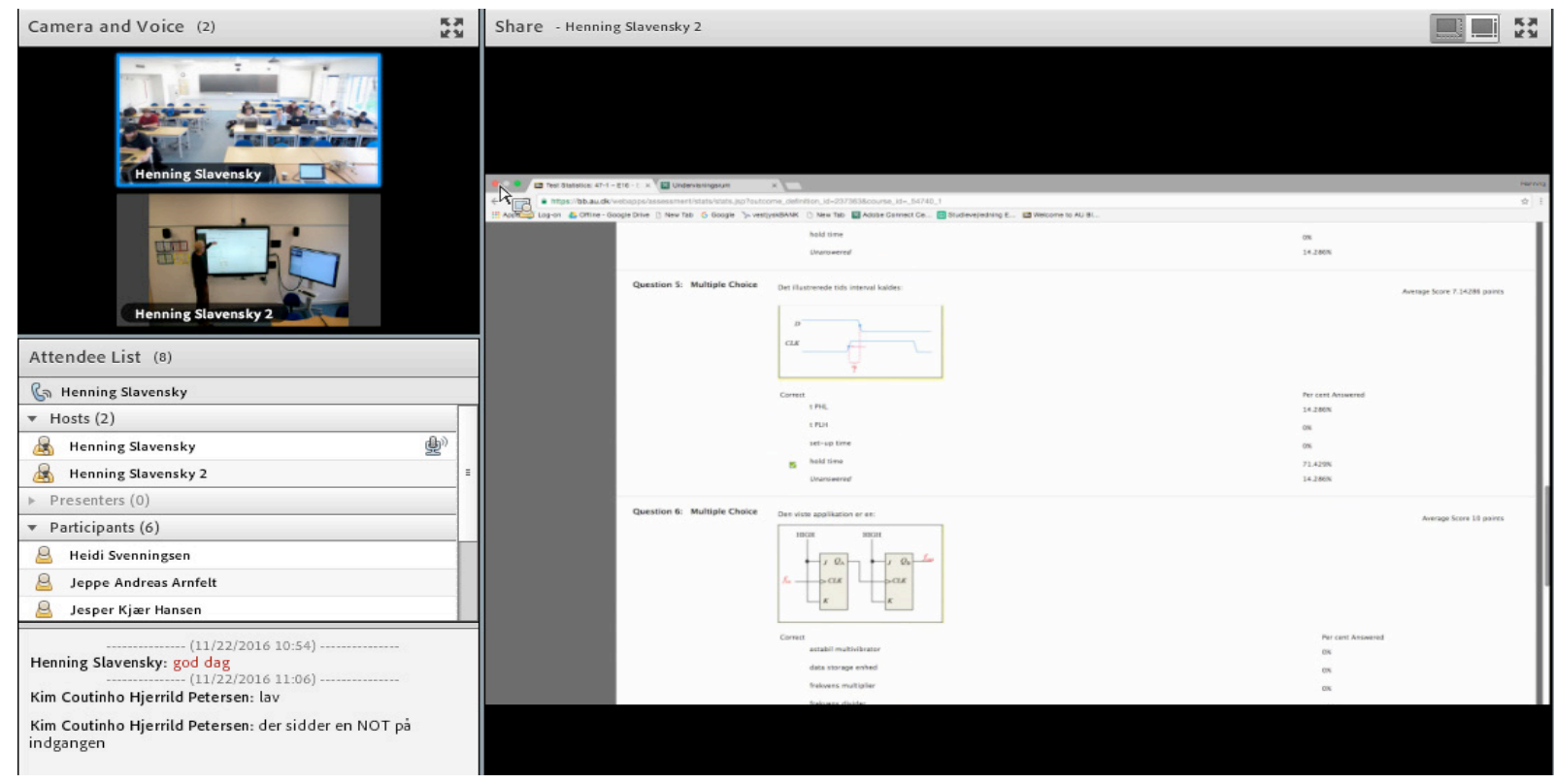

Figure 3: Screenshot from a face-to-face / online session via Adobe Connect. The set-up consists of a control PC with a 50" monitor and an 84" touchscreen connected to the educator's PC. The educator's desktop is projected to the touch screen and streamed. Two high-resolution pan-tilt-zoom (PTZ) cameras provide ambience and visual cues to the online students. Two-way sound is possible via microphones built into the ceiling and the attached loudspeakers.

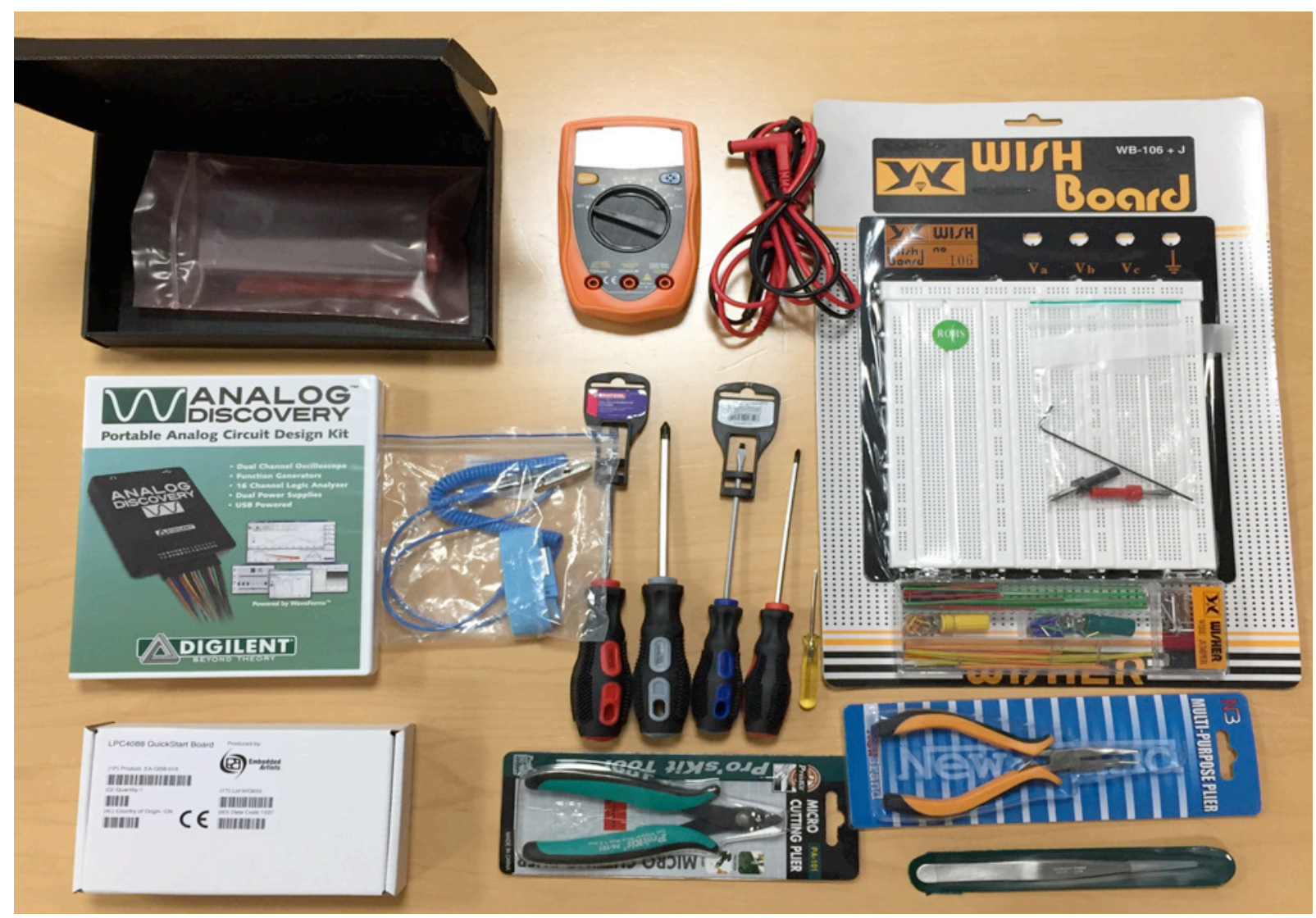

Figure 4: The 'lab-in-a-box' kit enables the students to perform active experimentation both on campus and at home and includes oscilloscope, mustimeter, breadboard for prototyping, embedded development platform (varies from semester to semester) and the necessary tools (optional) and bags/boxes for safe storage of electrical components. Components necessary for the various exercises and projects are shipped free of charge to the online students. A "Software-in-a-box" kit with preconfigured development tools, virtual machines is under development. 


\section{IMPACT}

The impact of the transformation has been positive seen from the perspective of the institution, educators and students. However, it has required major institutional and educational efforts in terms of development and training.

\subsection{Impact on the institution}

Seen from the institutional perspective, the student intake increased dramatically from 10 in 2014 to 37 in 2015 and to 38 in 2016 following an intensive marketing effort (Table 1), which saved the study programme. The initial results show that the study programme not only recruited students from across the country and age groups (and thus has provided students with the opportunity to study away from campus); it did also increase in learning results for both the face-to-face and the online students.

The one-year admission course in Herning also decided to go online at the same time as the Electronics Engineering study programme. The admission course is for students with vocational training who have not completed an upper secondary school and thus do not meet the ordinary admission requirements. By transforming the admission course into online learning, the student intake almost doubled from 2014 to 2016 (Table 1). The average age of the online admission course students is 35 . Most of the students have a family and a job, and find the online opportunity a suitable way to gain a higher education. $50 \%$ of the students plan to continue their studies at the online Electronics Engineering study programme; $50 \%$ want to continue their studies at another engineering programme elsewhere in Denmark.

Table 1. Student intake as of 1 October.

\begin{tabular}{|c|c|c|c|c|c|c|c|}
\hline Study programme & 2010 & 2011 & 2012 & 2013 & 2014 & 2015 & 2016 \\
\hline Electronics Engineering (face-to-face) & 26 & 30 & 20 & 16 & 10 & 22 & 12 \\
\hline Electronics Engineering (online) & - & - & - & - & - & 15 & 26 \\
\hline Admission course (face-to-face) & 26 & 27 & 25 & 12 & 16 & 12 & 13 \\
\hline Admission course (online) & - & - & - & - & - & 13 & 15 \\
\hline
\end{tabular}

In addition to the increased intake, the transformation of the programme was also in line with the institutional policy on 'educational IT' stating technology should be used to rethink courses and, among others, support students' learning [7].

\subsection{Impact on the educators}

The educator norm for a 5 ECTS course is usually 200 hours. A further 200 hours per 5 ECTS was allocated in order to flip the course. Due to the new approach on how the courses should be structured, these 200 extra hours were perceived as a minimum of what was needed for the initial transformation of the first courses. Aside from the usual renewal of learning materials and software, the educators now had to make their own videos and radically rethink the learning design of their courses. Furthermore, they had to attain the necessary skills to facilitate online classes via hands-on workshops. In this regard, the greatest challenge was to find a viable approach to conduct classes and exercises with online students (either synchronously or asynchronously).

From the first to second semester of the transformed study programme an increased confidence with the new tools and day-to-day course activities was observed among the educators. There is, however, still a lot of active experimentation taking place, and experiences of what works and what does not is shared actively at regular team meetings and workshops. Some positive side effects are 1) a new and deeper understanding of learning design and development as well as 2) the communication between educator-educator and educator-student, which has aligned the courses both with regard to the subject-matter and how they are presented. 


\subsection{Impact on the students}

Based on the evaluations of the 12 first-year courses conducted during the first year after the transformation, it was possible to assess the impact on various aspects of the students' studying and learning, and the effort the students had put into studying. The aggregated results are available in Table 2; however, due to the small number of students and the limited response rate (ranging between $24 \%$ and $32 \%$ ), the results must be subject to reservations.

Table 2. Impact on the Electronics Engineering students' learning.

\begin{tabular}{|c|c|c|c|c|}
\hline & \multicolumn{2}{|c|}{ Face-to-face students } & \multicolumn{2}{|c|}{ Online students } \\
\hline & Autumn 2015 & Spring 2016 & Autumn 2015 & Spring 2016 \\
\hline $\begin{array}{l}\text { Student } \\
\text { characteristics }\end{array}$ & \multicolumn{2}{|c|}{$\begin{array}{l}\text { All male, average age of } 23 \text { years (median } \\
=22 \text { YO) per January } 2016 .\end{array}$} & \multicolumn{2}{|c|}{$\begin{array}{c}\text { All male, average age of } 37 \text { years } \\
\text { (median = 38 YO) per January } 2016 .\end{array}$} \\
\hline \multicolumn{5}{|c|}{ Student effort } \\
\hline Time consumption & $\begin{array}{l}12.2 \text { hours per week } \\
\text { on average per } \\
\text { course in peak } \\
\text { periods equivalent to } \\
73 \text { hours per week. }\end{array}$ & $\begin{array}{l}8.8 \text { hours per week } \\
\text { on average per } \\
\text { course equivalent } \\
\text { to } 53 \text { hours per } \\
\text { week. }\end{array}$ & $\begin{array}{l}7.5 \text { hours per week } \\
\text { on average per } \\
\text { course equivalent } \\
\text { to } 45 \text { hours per } \\
\text { week. }\end{array}$ & $\begin{array}{l}5.3 \text { hours per week } \\
\text { on average per } \\
\text { course equivalent } \\
\text { to } 32 \text { hours per } \\
\text { week. }\end{array}$ \\
\hline $\begin{array}{l}\text { Attitude towards } \\
\text { technology in } \\
\text { education }\end{array}$ & $\begin{array}{l}67 \% \text { were to a high } \\
\text { or a very high extent } \\
\text { positive towards } \\
\text { initiatives involving } \\
\text { the use of new } \\
\text { technology in } \\
\text { education. } 33 \% \text { were } \\
\text { merely to some or a } \\
\text { less extent positive } \\
\text { towards technology } \\
\text { in education. }\end{array}$ & $\begin{array}{l}100 \% \text { were to a } \\
\text { high or a very high } \\
\text { extent positive } \\
\text { towards initiatives } \\
\text { involving the use of } \\
\text { new technology in } \\
\text { education. }\end{array}$ & $\begin{array}{l}100 \% \text { were a very } \\
\text { high extent positive } \\
\text { towards initiatives } \\
\text { involving the use of } \\
\text { new technology in } \\
\text { education. }\end{array}$ & $\begin{array}{l}100 \% \text { were to a } \\
\text { high or a very high } \\
\text { extent were positive } \\
\text { towards initiatives } \\
\text { involving the use of } \\
\text { new technology in } \\
\text { education. }\end{array}$ \\
\hline \multicolumn{5}{|l|}{ Impact on students } \\
\hline $\begin{array}{l}\text { Flexibility in time, } \\
\text { place and pace }\end{array}$ & $\begin{array}{l}67 \% \text { most frequently } \\
\text { participated in the } \\
\text { online activities } \\
\text { outside regular } \\
\text { lecturing hours } \\
100 \% \text { most } \\
\text { frequently } \\
\text { participated in the } \\
\text { activities at home. } \\
67 \% \text { most frequently } \\
\text { completed more than } \\
\text { one learning path in } \\
\text { one day. }\end{array}$ & $\begin{array}{l}100 \% \text { most } \\
\text { frequently } \\
\text { participated in the } \\
\text { online activities } \\
\text { outside regular } \\
\text { lecturing hours } \\
100 \% \text { most } \\
\text { frequently } \\
\text { participated in the } \\
\text { activities at home. } \\
80 \% \text { most } \\
\text { frequently } \\
\text { completed more } \\
\text { than one learning } \\
\text { path in one day, } \\
20 \% \text { completed } \\
\text { minor parts from } \\
\text { time to time. }\end{array}$ & $\begin{array}{l}100 \% \text { most } \\
\text { frequently } \\
\text { participated in the } \\
\text { online activities } \\
\text { outside regular } \\
\text { lecturing hours } \\
100 \% \text { most } \\
\text { frequently } \\
\text { participated in the } \\
\text { activities at home. } \\
100 \% \text { most } \\
\text { frequently used } \\
\text { more than one day } \\
\text { to complete one } \\
\text { learning path or } \\
\text { completed minor } \\
\text { parts from time to } \\
\text { time. }\end{array}$ & $\begin{array}{l}67 \% \text { most } \\
\text { frequently } \\
\text { participated in the } \\
\text { online activities } \\
\text { outside regular } \\
\text { lecturing hours } \\
100 \% \text { most } \\
\text { frequently } \\
\text { participated in the } \\
\text { activities at home. } \\
67 \% \text { most } \\
\text { frequently } \\
\text { completed more } \\
\text { than one learning } \\
\text { path in one day. }\end{array}$ \\
\hline $\begin{array}{l}\text { Satisfaction and } \\
\text { preferences }\end{array}$ & $\begin{array}{l}50 \% \text { preferred the } \\
\text { blended format as on } \\
\text { Electronics } \\
\text { Engineering to } 33 \% \\
\text { who preferred } \\
\text { traditional face-to- } \\
\text { face teaching }\end{array}$ & $\begin{array}{l}20 \% \text { preferred the } \\
\text { blended format as } \\
\text { on Electronics } \\
\text { Engineering to } 40 \% \\
\text { who preferred } \\
\text { traditional face-to- } \\
\text { face teaching }\end{array}$ & $\begin{array}{l}50 \% \text { preferred the } \\
\text { online format as on } \\
\text { Electronics } \\
\text { Engineering to } 25 \% \\
\text { who preferred } \\
\text { traditional face-to- } \\
\text { face teaching }\end{array}$ & $\begin{array}{l}100 \% \text { preferred the } \\
\text { online format as on } \\
\text { Electronics } \\
\text { Engineering. }\end{array}$ \\
\hline
\end{tabular}




\begin{tabular}{|c|c|c|c|c|}
\hline Learning outcome & $\begin{array}{l}83 \% \text { used the online } \\
\text { materials to a certain } \\
\text { or large extent for } \\
\text { deep learning } \\
\text { purposes. } \\
\text { On average across } \\
\text { all courses, } 38 \% \text { of } \\
\text { the students were } \\
\text { very satisfied, } 43 \% \\
\text { were satisfied, } 10 \% \\
\text { were neutral and } 9 \% \\
\text { were dissatisfied with } \\
\text { the learning } \\
\text { outcome. }\end{array}$ & $\begin{array}{l}100 \% \text { used the } \\
\text { online materials to } \\
\text { a certain, large or } \\
\text { very large extent for } \\
\text { deep learning } \\
\text { purposes. } \\
\text { On average across } \\
\text { all courses, } 38 \% \text { of } \\
\text { the students were } \\
\text { very satisfied, } 55 \% \\
\text { were satisfied, } 5 \% \\
\text { were neutral and } \\
2 \% \text { were } \\
\text { dissatisfied with the } \\
\text { learning outcome. }\end{array}$ & $\begin{array}{l}100 \% \text { used the } \\
\text { online materials to } \\
\text { a large or very } \\
\text { large extent for } \\
\text { deep learning } \\
\text { purposes. } \\
\text { On average across } \\
\text { all courses, } 17 \% \text { of } \\
\text { the students were } \\
\text { very satisfied, } 50 \% \\
\text { were satisfied, } 13 \% \\
\text { were neutral and } \\
20 \% \text { were } \\
\text { dissatisfied with the } \\
\text { learning outcome. }\end{array}$ & $\begin{array}{l}100 \% \text { used the } \\
\text { online materials to } \\
\text { a large or very } \\
\text { large extent for } \\
\text { deep learning } \\
\text { purposes. } \\
\text { On average across } \\
\text { all courses, } 17 \% \text { of } \\
\text { the students were } \\
\text { very satisfied, } 47 \% \\
\text { were satisfied, } 19 \% \\
\text { were neutral and } \\
17 \% \text { were } \\
\text { dissatisfied with the } \\
\text { learning outcome. }\end{array}$ \\
\hline
\end{tabular}

The results suggest that the students put a lot of effort into studying (32-73 hours per week), and, in particular, the face-to-face students were particularly busy during the first semester spending an average of up to 73 hours' studying per week in peak periods. The vast majority (i.e., $67-100 \%$ ) were positive or highly positive towards technology in education and the teaching format; however, the faceto-face students were less satisfied with their blended format compared to the online students who over time became highly satisfied with their online format. The online students were also less satisfied with the learning outcome compared to the face-to-face students. $64 \%-67 \%$ of the online students were satisfied or very satisfied with the learning outcome on average across all courses compared to $81 \%-83 \%$ of the face-to-face students. Both groups made good use of the flexibility in time, place and pace provided by the blended and online format, and in particular, the face-to-face students made more flexible use of the learning path over time by using the materials outside regular lecturing hours and/or covering more material in less time than expected. Also, the face-to-face students' use of the online materials changed over time towards a higher degree of deep learning purposes.

In other words, the evaluation results suggest that not only has the transformation made it possible to provide a programme online; it has also improved the existing programme by providing more flexible teaching and learning. The results also suggest that it may take time for the face-to-face students to make the best use of the blended format (which may also be related to the way the materials are designed and presented by the educators).

\section{CONCLUSIONS AND LESSONS LEARNT}

The project shows that it is indeed possible to 'energise' the engineering programme and increase student intake through marketing and by flipping the teaching to an online format and, at the same time, improving the learning for face-to-face students.

Continuous monitoring and interviews with the students have produced some valuable insights with regard to motivation, goals and barriers. The interviews show that by providing an online programme, a new group of students is now recruited for whom it would be difficult to obtain an engineering degree due to work and family obligations. These obligations, however, also make this group very vulnerable to changes with regards to family and work. The current rules and regulations governing the study progress for students with a full-time enrolment pose some challenges in this regard [8]. Alternative enrolment (e.g., signing up for single subject courses) is one way of dealing with these kinds of challenges, and is actively explored. It is, however, a relatively complex task to navigate the different kinds of enrolment effectively. Furthermore, careful consideration must be given to the mix of online and face-to-face students whose progression is asynchronous.

Single subject courses are also cultivated as a business opportunity for two new groups of students. The first group is students applying to the study programme with the intention of staying updated and gaining new knowledge and a more general skillset, but with only limited intentions of completing the degree. As with the more regular online students the flexibility means meeting demand that cannot be satisfied elsewhere. This kind of students, however, is potentially a drain on resources and morale in so far that their approach and commitment remains half-heartedly. Focus of the preliminary counselling of applicants will be to get this type of students enrolled on single-subject daytime courses, where they can pick and choose from the full curriculum as they prefer, instead of following the regular programme for a relatively modest fee of approximately 700 EUR per 5 ECTS. The second 
group is private sector employees who wants to obtain updated and more current knowledge and a more general skill-set either on their own or their company's initiative. Single subject daytime courses are competitively priced, offers flexibility and the option of obtaining a full degree.

A prerequisite for the successful launch in 2015 was that the project handled most aspects of the pedagogical and technical solution, including design, development, training and support. In order to scale and develop new programmes it is, however, necessary to generalise the lessons learned and get them embedded in the organisation along with the day-to-day operation. This has proved to be a somewhat challenging task in a complex organisation like AU. Any new endeavour would be ill advised not to take this task into careful consideration. Such is often the price of being a first mover but in context of this project it turned out to be a lifesaver. All-in-all the flipping of the study programme resulted in a complete turn-around of the engineering education in Herning in less than one year and the intake of new students in 2016 was at record high of 38 new engineering students and 28 admission course students.

\section{ACKNOWLEDGEMENTS}

Thanks to all the educators for the engagement in the process and to Charlotte Kejser Rasmussen for proofreading.

\section{REFERENCES}

[1] Unpublished memorandum, "Online uddannelse - Elektroingeniør i Herning”, 2015.

[2] IDEO, "Design Thinking for Educators," $2^{\text {nd }}$ edition, http://www.designthinkingforeducators.com/

[3] R. G. Cooper, "Stage-gate Systems: A New tool for Managing New Products", Business Horizons, May-June 1990, vol 33 (3).

[4] E. Mazur and R. C. Hilborn. Peer instruction: A user's manual. Physics Today, 50(4), pp. 68-69. 1997.

[5] G. M. Novak, E. T. Patterson, A. D. Gavrin, and W. Christian. Just-in-Time Teaching: Blending Active Learning with Web Technology. Upper Saddle River, NJ: Prentice Hall. 1999.

[6] M. Godsk. "STREAM: a Flexible Model for Transforming Higher Science Education into Blended and Online Learning". in T. Bastiaens \& G. Marks (Eds.), Proceedings of World Conference on E-Learning in Corporate, Government, Healthcare, and Higher Education 2013 Chesapeake, VA: AACE. pp. 722-728. 2013.

[7] Aarhus Universitet. "Den faglige udviklingsproces. Øvrige bilag", http://medarbejdere.au.dk/strategi/historiskeprojektsites/udviklingsproces2011/faktaomforandringernehvaderbesluttet/tvaerinitiv/kvalitetoged ucationalit/mereomeducationalit/, 2011.

[8] The Danish Government. "Bedre igennem uddannelserne - Reform af SU-systemet Uddannelses- og Forskningsministeriet”, http://ufm.dk/publikationer/2013/filer-2013/bedreigennem-uddannelserne-reform-af-su-systemet.pdf, 2013. 